Journal of Fisheries International 7 (1): 20-25, 2012

ISSN: $1817-3381$

(C) Medwell Journals, 2012

\title{
Endosymbiotic Perspectives, Bioactive Compound Identification and its Protein Profile from Chosen Marine Sponges
}

\author{
K.V. Anitha and A.U. Manjusha \\ International Centre for Bioresources Management, Malankara Catholic College, \\ Mariagiri, Kaliakkavilai, 629153 Kanyakumari District, Tamil Nadu, India
}

\begin{abstract}
Today, one of the emerging source of small molecule drug lead in the world's ocean. Based on the present findings, the sponge extract from Zygomycale parishi have potential anti-microbial activity against pathogenic bacteria and fungi. Endosymbiotic bacteria and actinomycetes were isolated from the sponge. Marine actinomycetes are recognized as the rich source of secondary. In this study, it is shown that extracts from the sponge derived actinomycetes also provide good source for the discovery of anti-microbial compounds. Endosymbiotic actinomycetes shows excellent activity against Pseudomonas species and its activity against Bacillus subtilis are feeble. Protein profiling reveals the band which indicates that the fraction obtained might have responsible potential anti-microbial activity. In SDS-PAGE protein profile study shows on crude toxins yielded nine bands in Halichondria panicea aqueous extract ranging from 14.3-116 kDa with three well-defined bands at 19.5, 39.0 and $66.2 \mathrm{kDa}$. The compound responsible for the anti-microbial activity in both sponge and its endosymbiotic actinomycetes has to be isolated and can be used for the drug development against diseases.
\end{abstract}

Key words: Endosymbiotic actinomycetes, marine sponge, Zygomycale parishi, Denrilla membranosa, drug, India

\section{INTRODUCTION}

The marine environment, particularly with sponges is a rich source of new bioactive metabolites 287 novel metabolites was isolated from marine sponges in 2008 (Blunt et al., 2010). The availability of biomass is a limiting factor for isolating marine natural products. The widespread isolation of typical microbial metabolites from sponges leads to the hypothesis that these metabolites are in fact the products of microbial metabolism (Zhang et al., 2006). Sponges are grouped in to 4 classes, the Hexactinellida (glass sponges), the Calcarea (calcarious sponges), Sclerospongiae (coralline or tropical reef sponges) and the Demospongiae. The widespread isolation of typical microbial metabolites from sponges leads to the hypothesis that these metabolites are in fact the products of microbial metabolism described by Fortman and Sherman (2005), Palpandi et al. (2007) and Nagasathya and Thajuddin (2008). The isolation of secondary metabolite-producing bacteria from sponges and of microbial secondary metabolism gene clusters from the metagenome of sponges has led to the general understanding that these metabolites are in many cases, the products of microbial symbionts and are not derived from the microbial diet of sponges (Kennedy et al., 2009).
A number of reports have been published on the isolation of actinobacteria from marine organisms ( $\mathrm{Li}, 2009$; Izumikawa et al., 2010). Very recently, several researchers were reported and investigated the screening bioactive substances from these marine-derived actinobacteria has yielded several new bioactive metabolites (Lin et al., 2010; Li et al., 2011; Sujatha and Joseph, 2011). The occurrence of large scale of bioactive compounds is not common to all living organisms but restricted to certain taxonomic groups.

Among marine animals, reef's invertebrates are the most prolific producers of secondary metabolites and have become sources of great interest to natural product chemistry, since they provide a large proportion of bioactive compounds with different biological activities described by Radjasa et al. (2007).

Sponges have been recognized as rich sources of novel compounds that are potential interest to mankind. Another fact that has been recognized is that virtually all sponges contain endosymbiotic microorganisms and these symbionts often contribute considerably to the total sponges biomass (Bharath et al., 2008). Sponges have been shown to harbor a large number of bacteria in some cases $>60 \%$ of the tissue volume. Microorganisms detected so far in sponges include archaea, heterotrophic

Corresponding Author: K.V. Anitha, International Centre for Bioresources Management, Malankara Catholic College, Mariagiri, Kaliakkavilai, 629153 Kanyakumari District, Tamil Nadu, India 
bacteria, cyanobacteria, red and green algae, dinoflagellates and diatoms (Hentschel et al., 2002, 2003; Hill, 2004; Javanshir et al., 2008). Marine sponges were provided with the largest number of marine derived secondary metabolites including some of the most interesting pharmacologically important drug candidates (Lam, 2006). A series of kalihinols, deterpenes isolated from the Philippine marine sponge Acanthella cavernosa, as potential bacterial foliate biosynthesis inhibitors. Very few researchers have been studied this kind of sponge species and its bioactivities. There is very ample of researches been developed. Since, the present study makes an attempt to find out the bioactive potential of sponge extract and associated actinomycetes.

\section{MATERIALS AND METHODS}

Preparation of crude extracts: The sponges collected in methanol containers were squeezed in a tissue homogenizer depending on the nature of the sponge species which was used for extraction. In the case of Mycale and Dendrilla species, they were cut into small pieces and squeezed to prepare the crude extract using a mortar and pestle using methanol as solvent. They were extracted thrice and the combined extract was concentrated in a rotary vacuum evaporator at room temperature. Thus, concentrated crude extract was collected in air tight plastic containers and kept in refrigerator. The aqueous extract of sponge was prepared by squeezing the sand-free specimens in triple distilled water. The resultant solution was filtered and dialyzed using dialysis membrane against $\mathrm{D}$-glucose to remove the excess water. The supernatant obtained was lyophilized and stored at $4^{\circ} \mathrm{C}$ in a refrigerator for further use as aqueous crude extract for SDS-PAGE.

Anti-bacterial activity of sponge extract against pathogenic bacteria

Preparation of sponge extract: From an initial $10 \mathrm{~g}$ sample of dried sponge tissue, methanolic and chloroformmethanol (2:1) extraction, yielded, respectively 1.970 and $0.520 \mathrm{~g}$ of crude toxin while aqueous extraction yielded $3 \mathrm{~g}$.

Estimation of protein: The crude protein contents were found to be 0.096 and $0.192 \mathrm{mg} \mathrm{mL}^{-1}$, respectively in methanolic and chloroform-methanol extracts and $0.124 \mathrm{mg} \mathrm{mL}^{-1}$ in aqueous extract. It ranged from below detectable levels to $0.014 \mathrm{mg} \mathrm{mL}^{-1}$ in methanolic extract fractions and from below detectable levels to $0.002 \mathrm{mg}$ $\mathrm{mL}^{-1}$ in aqueous extract.

Microorganism material: The sponge-associated actinobacterium Streptomyces microflavus was isolated from the inner tissue of the marine sponge Hymeniacidon perlevis collected from the inter-tidal beach of the Yellow Sea at Dalian, China ( $\left.38^{\circ} 52^{\prime} \mathrm{N}, 121^{\circ} 41^{\prime} \mathrm{E}\right)$ in March, 2003. Sponge specimens were placed in plastic bags containing seawater and immediately transported to the laboratory. Actinobacteria identification was carried out by the method reported by Zhang et al. (2006).

Filter Paper Disc Method: The anti-microbial susceptibility testing was done by Kirby-baeur Disc Diffusion Method. This method allows the rapid determination of the efficacy of a drug by measuring the diameter of the zone of inhibition that result from diffusion of the agent into the medium surrounding the disc. In this procedure, filter paper discs of uniform size $(6 \mathrm{~mm})$ are impregnated with specified concentrations of two methanolic sponge extract and then placed on the surface of an agar plate that has been seeded with the organisms to be tested. The medium of choice is Mueller-Hinton agar with $\mathrm{pH}$ of 7.2-7.4 which is poured into plates to uniform depth of $5 \mathrm{~mm}$ and refrigerated on solidification. Label the covers of each plate with the name of test organisms to be inoculated. Bacterial colonies were allowed to grow overnight at $37^{\circ} \mathrm{C}$ then the inhibition zone around the disc was measured.

Anti-fungal activity of sponge extract against fungi: Petri dishes with Rose Bengal agar medium were inoculated with four isolated fungi. Round paper discs of $6 \mathrm{~mm}$ were dipped in to $0.001 \mathrm{~mL}$ of each methanolic sponge extract and placed in the centre of the inoculated petri dish. Fungal colonies were allowed to grow overnight at $20^{\circ} \mathrm{C}$ and then the inhibition zone around the disc was measured.

Sponge was collected by scuba divers from South West coast of India. Voucher specimens were either preserved in $70 \%$ ethanol immediately upon collection or freeze-dried for chemical characterization. Freeze-dried specimens were prepared for histology by dehydration in a very weak solution of detergent for $24 \mathrm{~h}$ followed by preservation in $70 \%$ ethanol. Histological sections and spicule preparations were made as in the research of Kelly-Borges and Vacelet. Specimens are stored for the long term in $70 \%$ ethanol. Voucher specimens representing material that was chemically characterized were registered with the Natural History Museum and specimens are deposited in their sponge collections.

The sponges collected in methanol containers were squeezed in a tissue homogenizer depending on the nature of the sponge species which was used for extraction. In the case of Mycale species, they were cut into small pieces and squeezed to prepare the crude extract using a mortar and pestle using methanol as solvent. They were extracted thrice and the combined 
extract was concentrated in a rotary vacuum evaporator (Buchi, Flawil and Switzerland) at room temperature. Thus, concentrated crude extract was collected in air tight plastic containers and kept in refrigerator.

SDS-PAGE analysis of protein profile: One dimension Sodium Dodecyl Sulphate (SDS) Polyacrylamide Gel Electrophoresis (PAGE) was carried out. The protein content of methanolic crude extract and aqueous crude extract were dissolved in $300 \mu \mathrm{L}$ of sample buffer and the samples were loaded into several lanes of $30 \%$ gradient gel along with the molecular weight standards. The process adapted a power supply of 80 volts for $3 \mathrm{~h}$. After electrophoresis, the gel was stained with silver staining.

Procedure for silver staining: After running one dimensional gel incubate the gel in Fixer ( $40 \%$ ethanol, $10 \%$ acetic acid, $50 \%$ water) for $1 \mathrm{~h}$. Wash the gel in $\mathrm{H}_{2} \mathrm{O}$ for atleast $30 \mathrm{~min}$. Sensitized the gel in $0.02 \%$ sodium thiosulphate for only $1 \mathrm{~min}$, wash gel in $\mathrm{H}_{2} \mathrm{O}$ for $3 \times 20 \mathrm{sec}$. Place the gel in a new staining tray wash gel in $\mathrm{H}_{2} \mathrm{O}$ for $1 \mathrm{~min}$. Develop the gel in 30\% sodium carbonate, $0.05 \%$ formaldehyde. Change developer solution immediately after when it turns yellow. Terminate when the staining is sufficient. Wash the gel in $\mathrm{H}_{2} \mathrm{O}$ for $20 \mathrm{sec}$. Terminate staining in $5 \%$ acetic acid for $5 \mathrm{~min}$. Leave the gel at $4^{\circ} \mathrm{C}$ in $1 \%$ acetic acid for storage.

The aqueous extract of sponge was prepared by squeezing the sand-free specimens in triple distilled water. The resultant solution was filtered and dialyzed using dialysis membrane against D-glucose to remove the excess water. The supernatant obtained was lyophilized and stored at $4^{\circ} \mathrm{C}$ in a refrigerator for further use as aqueous crude extract for SDS-PAGE.

The crude extracts were purified by ammonium sulphate precipitation. During ammonium sulphate precipitation, the salt has to be preventing increase of high local concentration. Ammonium sulphate was used for precipitation of total proteins at $-90 \%$ saturation or for precipitation of proteins using different saturations of salt $40 \%$ saturation was done to precipitate the proteins from the culture. The solution was equilibrated for approximately one day in cold condition to ensure complete precipitation and then the precipitate was collected by centrifugation and it was further purified by dialysis method using dialysis membrane. Thus prepared were used for 1 dimension Sodium Dodecyl Sulphate (SDS) Polyacrylamide Gel Electrophoresis (PAGE) was carried out. The protein content of methanolic crude extract and aqueous crude extract were dissolved in $300 \mu \mathrm{L}$ of sample buffer and the samples were loaded into several lanes of $30 \%$ gradient gel along with the molecular
Table 1: Quantification of endosymbiotic actinomycetes DNA from Zygomycale parishii and Dendrilla membranosa OD of endosymbiotic bacteria

\begin{tabular}{|c|c|c|}
\hline \multirow[b]{2}{*}{$\begin{array}{l}\text { Endosymbiotic } \\
\text { actinomycetes }\end{array}$} & \multicolumn{2}{|c|}{ 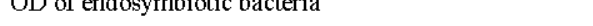 } \\
\hline & Zygomycale parishii (nm) & Dendrillamembronosa(nm) \\
\hline & 1.790 & 1.742 \\
\hline $\mathrm{ES} 2$ & 1.723 & 1.776 \\
\hline ES3 & 1.754 & 1.845 \\
\hline ES4 & 1.664 & 1.734 \\
\hline ES5 & 1.690 & 1.800 \\
\hline
\end{tabular}

weight standards. The process adapted a power supply of 80 volts for $3 \mathrm{~h}$. After electrophoresis, the gel was stained with silver staining.

Quantification of DNA from the sponge: DNA extraction of Zygomycale parishi was carried by Lysis Buffer with Cetyl Trimethyl Ammonium Bromide (CTAB). Homogenization of sponge fragments in 1:3 (weight: volume) solution of $2 \% \mathrm{CTAB}$ in $100 \mathrm{mM}$ Tris- $\mathrm{HCl}$ $\mathrm{pH} 8.0,20 \mathrm{mM}$ EDTA, $1.4 \mathrm{M} \mathrm{NaCl}$ plus $1 \mu \mathrm{L} \beta-$ mercaptoetanol and $10 \mu \mathrm{g} \mu \mathrm{L}^{-1}$ proteinase $\mathrm{K}$. The suspension was incubated at $50^{\circ} \mathrm{C}$ for at least $1 \mathrm{~h}$ and centrifuged at $3000 \mathrm{~g} / 10 \mathrm{~min}$. The supernatant was extracted twice with one volume of chloroform:isoamyl alcohol (24:1). Precipitate DNA from the homogenate by the addition of 0.8 volumes of isopropanol plus $1 / 10$ volume of $3 \mathrm{M}$ sodium acetate $\mathrm{pH} 5.2$, followed by centrifugation at $10000 \mathrm{~g} / 10 \mathrm{~min}$ at $4^{\circ} \mathrm{C}$. The pellet was washed in 70\% ethanol, air dried, dissolved in sterile water plus $20 \mu \mathrm{g} \mathrm{mL} \mathrm{m}^{-1} \mathrm{RNAse} A$ and incubated for $1 \mathrm{~h}$ at $37^{\circ} \mathrm{C}$. The concentration and purity of bacterial and sponge DNA were determined spectrophotomectrically for this purpose, DNA absorbance was measured at $260 \mathrm{~nm}$ (DNA $\mu \mathrm{g} \mathrm{g}^{-1}$ sample; 1 A $260=50 \mu \mathrm{g} \mathrm{mL}^{-1} \mathrm{DNA}$ ) and protein impurities were checked at $280 \mathrm{~nm}$ (Table 1).

\section{RESULTS AND DISCUSSION}

\section{Anti-bacterial activity of Zygomycale parishii and} Dendrilla membranosa against pathogenic bacteria: Present study revealed that the tested in marine sponge Zygomycale parishii possessed potential anti-bacterial activity against Azetobacter sp., B. cereus, B. subtilis, Glucanobactor oxydens, Pseudomonas aeruginosa (Table 2, Fig. 1). While tested by the disc diffusion method, methanolic sponge extract of Zygomycale parishii showed significant activity against $B$. subtilis and Glucanobactor oxydans produced minimum inhibitory activity $18.7 \mathrm{~mm}$. Among the five species of bacteria sponge methanolic extract showing highly significant anti-bacterial activity against $P$. aeruginosa. Another sponge of Dendrilla membranosa extracts showed maximum anti-bacterial activity of $18 \mathrm{~mm}$, Azetobacter sp., followed by Glucanobactor oxydans $16 \mathrm{~mm}$. Though, optimum as well as least activity 
observed $14 \mathrm{~mm}$ in case of B. subtitlis and $12 \mathrm{~mm}$ in case of $B$. cereus, respectively. Of these two marine sponges, Zygomycale parishii extract consist of similar zone of inhibition observed $18 \mathrm{~mm}$ in B. subtitlis and B. cereus. Furthermore, biochemical characterization was observed results were shown on Table 3 .

Anti-fungal activity of Zygomycale parishii and Dendrilla membranosa against fungi: Here, it was found that the extracts successfully prevent the growth of fungi. The inhibitory zone produced by extract against Aspergillus aculeatus 12 and $18 \mathrm{~mm}$, Aspergillus niger was 12.5 and $15 \mathrm{~mm}$, Candida tropicalis is 9 and $16.5 \mathrm{~mm}$ and $R$. micchii for 14 and $16 \mathrm{~mm}$, respectively. Among this, Zygomycale parishii showed more activity against R. micchii (14 $\mathrm{mm}$ ) followed by Aspergillus niger $(12.5 \mathrm{~mm})$ and Candida tropicalis $(9 \mathrm{~mm})$. The extract shows feeble activity against Aspergillus aculeatus $(12 \mathrm{~mm})$. In case of Dendrilla membranosa, it had higher activity against all the four fungi.

Anti-bacterial activity of endosymbiotic actinomycetes from $Z$. parishii and Denrilla membranosa: The anti-bacterial activity screening was performed by agar well method against the standard test organisms such as $B$. subtilis, $P$. aeruginosa, $P$. fluorescens. Actinomycetes have high activity against Pseudomonas

Table 2: Bioactivity of endosymbiotic actinomycetes from two marine

\begin{tabular}{lcccc}
\multicolumn{5}{c}{ sponges, $Z$ parishii and $D$. membronosa } \\
\hline Bacteria & ESAcA1 & ESAcA2 & ESAcB1 & ESAcB2 \\
\hline Bacillus subtilis & 8 & 9.2 & 7.5 & 10.2 \\
Pseudomonas aeroginosa & 14 & 12.5 & 10.7 & 18.0 \\
Pseudomonas fluorescens & 12 & 18.5 & 20.2 & 13.8 \\
\hline
\end{tabular}

aeruginosa and pseudomonas fluorescens while its activity was feeble against Bacillus subtilis (Fig. 2). By

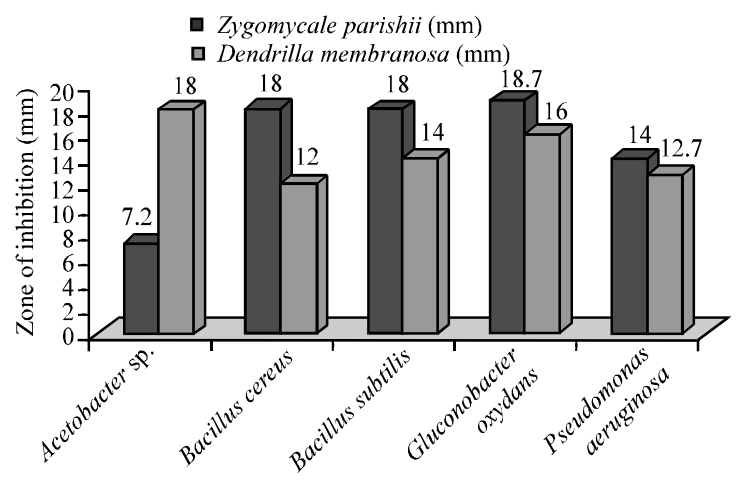

Fig. 1: Anti-bacterial activity of sponges (Z. parishii and D. membranosa) against bacteria

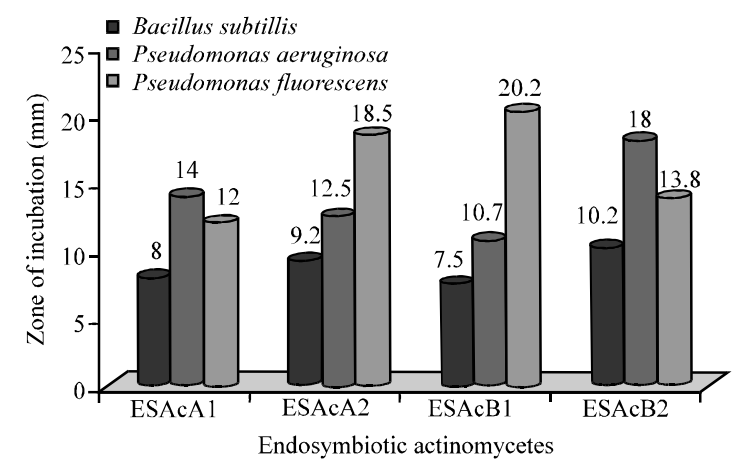

Fig. 2: Anti-bacterial activity of endosymbiotic actinomycetes from $Z$. parishii and Denrilla membranosa

Table 3: Biochemical characterization of endosymbionts from $Z$ parishii

\begin{tabular}{|c|c|c|c|c|c|c|c|c|c|}
\hline Bacterial isolates & Casein & Catalase & Citrate & Indole & $\mathrm{H}_{2} \mathrm{~S}$ & MR & Oxidase & Urease & $\mathrm{VP}$ \\
\hline $\begin{array}{l}\text { ESA1 Endosymbionts from } \\
\text { Zygomycale parishii }\end{array}$ & + & - & + & + & - & + & - & + & + \\
\hline ESA2 & + & - & - & - & - & - & - & + & - \\
\hline ESA3 & + & - & + & + & - & ++ & - & + & + \\
\hline ESA4 & + & - & - & + & - & ++ & + & + & + \\
\hline ESA5 & - & - & - & + & - & ++ & - & + & + \\
\hline ESA6 & - & - & + & + & - & ++ & + & + & - \\
\hline ESA7 & + & - & - & + & - & - & + & + & - \\
\hline ESA8 & + & + & - & + & - & + & - & + & - \\
\hline ESA9 & + & + & + & + & - & + & - & + & + \\
\hline ESA10 & + & - & - & - & - & + & - & + & + \\
\hline ESA11 & + & - & + & - & - & + & - & + & - \\
\hline ESA12 & + & + & + & + & - & - & + & + & + \\
\hline ESA13 & + & + & + & + & + & ++ & - & + & + \\
\hline ESA14 & + & + & + & + & - & + & - & + & + \\
\hline ESA15 & + & - & - & + & - & + & - & + & + \\
\hline ESAcA1 & + & + & + & - & - & + & - & + & + \\
\hline ESAcA2 & + & - & + & + & + & + & - & - & + \\
\hline ESAcA3 & + & - & + & + & - & + & - & - & - \\
\hline $\mathrm{ESAcA} 4$ & + & + & + & + & + & ++ & + & + & - \\
\hline ESAcA5 & + & - & + & - & + & ++ & - & + & + \\
\hline
\end{tabular}

$(+)$ : Positive; (-): No response; (++): Maximum 


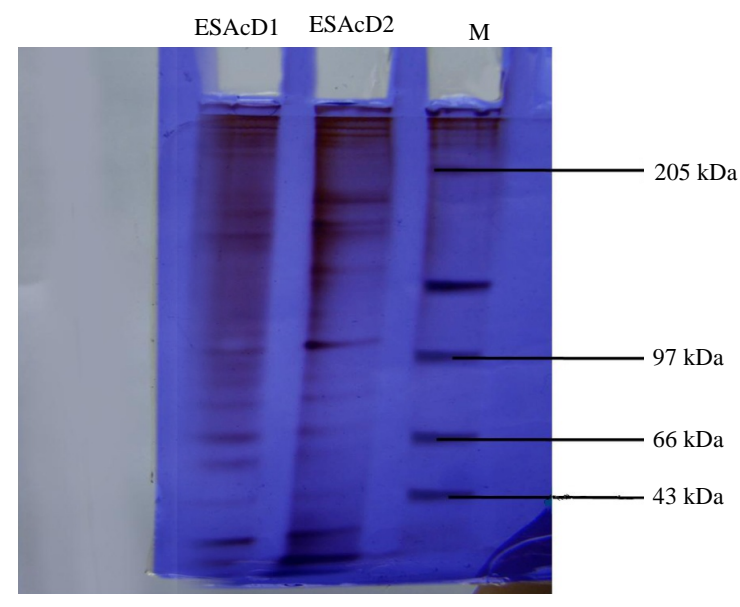

Fig. 3: SDS-PAGE analysis of endosymbionts from two different experimental sponges

SDS-PAGE on $12 \%$ gel, crude toxins yielded nine bands in Halichondria panicea aqueous extract, ranging from $14.3-116 \mathrm{kDa}$ with three well-defined bands at $19.5,39.0$ and $66.2 \mathrm{kDa}$ (Fig. 3). Moreover, the appeared banding patterns (higher molecular weight) were randomly present on the ESAcD2 compared with ESAcD1. In case of lower molecular weighed bands range between 43-97 were visibly appeared in ESAcD1 but in ESAcD2 having lower banding patterns were looking faded in nature. Though, $97 \mathrm{kDa}$ band alone clearly visible in ESAcD2 than remaining bands.

In the present study, sponges Zygomycale parishii and Dendrilla membranosa collected from Vizhinjam coastal area, produced potent anti-microbial extracellular products. This property indicates that the species might have defense mechanisms in the host sponge. These sponges has extreme potent of anti-fungal and antibacterial activity (Chelossi et al., 2006). Previously, most of the researchers have been studied. Despite the crude of aqueous and chloroform extracts at different concentration of 5,10 and $15 \mathrm{mg} \mathrm{mL}^{-1}$ were tested against 6 species of bacteria such as Pseudomonas sp., Streptococcus aureus, Vibrio parahaemolyticus, $V$. cholerae, E. coli and $V$. parahaemolyticus and 3 species of fungus namely; $A$. flavis, $A$. niger and Candida albicans. From this results agreed with the researchers viewed by Ankudey et al. (2008) and that the crude aqueous extract inhibit the growth of $V$. cholerae where as in the chloroform extract a clear inhibition zone were observed only against Pseudomonas sp. The present study indicated the closely related bacterial species present with in these sponges reported the findings about the endosymbiotic relationship with the sponges (Montalvo et al., 2005). Among the ten isolates, four strains of white series were selected and characterized by conventional methods and assessed for their antagonistic activity against fish pathogens like Aeromonas hydrophila and Vibrio sp. All the strains showed inhibitory activity against these fish pathogens (Safaein et al., 2009).

\section{CONCLUSION}

In this study depicted screening for pharmacologically active agents from marine actinomycetes, the researchers found that petroleum ether and ethyl acetate culture broth of Nocardiopsis sp. VITSVK5 (FJ973467) was found to be active against selected microbial pathogens (Boobathy et al., 2009). Furthermore, the present study also been agreed by Radjasa et al. (2007) with them opinion that marine bacteria associated with sponge Haliclona sp. showed strong growth inhibition against indicator microorganisms. Moreover, marine bacteria are emerging as an exciting species for the discovery of new classes of therapeutics and it could provide the drugs needed to sustain us for the next 100 years in our battle against drug resistant infectious diseases (Molinski, 2004; Williams, 2009) and which exhibited weak anti-fungal activity against Alternaria alternate (Usama et al., 2010). Indian marine sediment samples few potential bioactive Nocardiapsis have been reported. A protease-producing, crude oil degrading marine Nocardiopsis sp., NCIM 5124 have been reported (Dixit and Pant, 2000).

\section{ACKNOWLEDGEMENTS}

The researchers are deeply gratefulness to the Malankara Catholic College Correspondent Rev. Fr. Prem Kumar. (M.S.W) given encouragement and support for preparation of this research manuscript. The researchers also thankful to the Department of Biotechnology Faculties and Lab Assistant for them help.

\section{REFERENCES}

Ankudey, F.J., P. Kiprof, E.R. Stromquist and L.C. Chang, 2008. New bioactive bromotyrosine derived alkaloid from a marine sponge Aplysinella sp. Planta Med., 74: 555-559.

Bharath, G., P.D. Priya, S.S. Chinnu, D. Jini and J. Janika et al., 2008. Anti-bacterial activity of marine sponges from rocky reefs of south west cost of India. J. Basic Applied Biol., 2: 87-93. 
Blunt, J.W, B.R. Copp, M.H.G. Munro, P.T. Northcote and M.R. Prinsep, 2010. Marine natural products. Nat. Prod. Rep., 27: 165-237.

Boobathy, S., P. Soundarapandian, V. Subasri, N. Vembu and V. Gunasundari, 2009. Bioactivities of protein isolated from marine sponge Sigmadocia fibulatus. Curr. Res. J. Biol. Sci., 1: 160-162.

Chelossi, E., I. Mancini, K. Sepcic, T. Turk and M. Faimali, 2006. Comparitive anti-bacterial activity of polymeric 3-alkylpyridinium salts isolated from the Mediterranean sponge Reniera sarai and their synthetic analogues. Biomol. Eng., 23: 317-323.

Dixit, V. and A. Pant, 2000. Comparative characterization of two serine endopeptidases from Nocardiopsis sp. NCIM 5124. Biochim. Biophys. Acta, (BBA) General. subjects, 1523: 261-268.

Fortman, J.L and D.H. Sherman, 2005. Utilizing the power of microbial genetics to bridge the gap between the promise and the application of marine natural products. Chem biochem., 6: 960-978.

Hentschel, U., J.Hopke, M. Horn, Friedrich, A.B. Wagner, J. Hacker and B.S. Moore, 2002. Molecular evidence for a uniform microbial community in sponges from different oceans. Applied Environ. Microbiol., 68: 4431-4440.

Hentschel, U., L. Fieseler, M. Wehrl, C. Gernert, M. Steinert, J. Hacker and M. Horn, 2003. Microbial Diversity of Marine Sponges. In: Sponges (Porifera), Muller, W.E.G. (Ed.). Springer-Verlag, New York, USA., ISBN-13: 9783540009689 , pp: 59-88.

Hill, R.T., 2004. Microbes from Marine Sponges: A treasure Trove of Biodiversity for Natural Products Discovery. In: Microbial Diversity and Bioprospectin, Bull, A.T. (Ed.). Center of Marine Biotechnology, University of Maryland Biotechnology Institute, Columbus, pp: 177-190.

Izumikawa, M., S.T. Khan, M. Takagi and K. Shin-Ya, 2010. Sponge-derived Streptomyces producing Isoprenoids via the mevalonate pathway. J. Nat. Prod., 73: 208-212.

Javanshir, A., M. Shapoori and S. Jamili, 2008. Diversity of benthic invertebrates fauna and secondary production in Southern Caspian Sea Basin, case study on Tajan River Estuary. J. Fish. Aquatyic Sci., 3: 353-365.

Kennedy, J., P. Baker, C. Piper, P.D. Cotter and M. Walsh et al., 2009. Isolation and analysis of bacteria with anti-microbial activities from the marine sponge Haliclona simulans collected from Irish waters. Mar. Biotechnol., 11: 384-396.
Lam, K.S., 2006. Discovery of novel metabolites from marine actinomycetes. Curr. Opin. Microbiol., 9: 245251.

Li, K., Q.L. Li, N.Y. Ji, B. Liu, W. Zhang and X. Peng, 2011. Caoleoxyuridines from the marine sponge associated actinomycete Streptomyces microflavus. Mar Drugs, 9: 690-695.

Li, Z., 2009. Advances in marine microbial symbionts in the China Sea and related pharmaceutical metabolites. Mar. Drugs, 7: 113-129.

Lin, Z., R.R. Antemano, R.W. Hughen, M.D.B. Tianero and O. Peraud et al., 2010. Pulicatins A-E, neuroactive thiazoline metabolites from cone snailassociate bacteria. J. Nat Prod., 73: 1922-1926.

Molinski, T.F., 2004. Anti-fungal compounds from marine organisms. Curr. Med. Chem., 3: 197-220.

Montalvo, N.F., N.M. Mohamed, J.J. Enticknap and R.T. Hill, 2005. Novel actinobacteria from marine sponges. Antonie Leeuwenhoek, 87: 29-36.

Nagasathya, A. and N. Thajuddin, 2008. Diatom diversity in hypersaline environment. J. Fish. Aquatyic Sci., 3: 328-333.

Palpandi, C., G. Ananthan and A. Shanmugam, 2007. Cryptofaunal associates of Spirastrella inconstans (Dendy) and $S$. inconstans var. digitata (Dendy), the coral reef sponges of palk bay. J. Fish. Aquat. Sci., 2: 71-76.

Radjasa, O.K., A. Sabdono, Junaidi and E. Zocchi, 2007. Richness of secondary metabolite-producing marine bacteria associated with sponge Haliclona sp. Int. J. Pharmacol., 3: 275-279.

Safaein, S., H. Hosseini, A. Abbas Pour, A. Sadolah and S. Farmohamadi, 2009. Anti-microbial activity of marine sponge extracts of offshore zone from Nay Band Bay, Iran. J. Med. Mycolog, , 19: 11-16.

Sujatha, S. and B. Joseph, 2011. Effect of few marine sponges and its biological activity against Aedes aegypti Linn. Musca domestica (Linnaeus, 1758) (Diptera: Culicidae). J. Fish. Aquat. Sci., 6: 170-177.

Usama, R.A., S.M. Pimentel-Elardo, A.H. Mona Radwan, Soad H. Abou-El-Ela, Safwat Ahmed and H. Ute, 2010. Isolation, phylogenetic analysis and antiinfective activity screening of marine spongeassociated actinomycetes. Mar. Drugs, 8: 399-412.

Williams, P.G., 2009. Panning for chemical gold: Marine bacteria as a source of new therapeutics. Trends Biotechnol., 27: 45-52.

Zhang, H., Y.K. Lee, W. Zhang and H.K. Lee, 2006. Culturable actinobacteria from the marine sponge Hymeniacidon perleve: Isolation and phylogenetic diversity by $16 \mathrm{~S}$ rRNA gene-RFLP analysis. Antonie van Leeuwenhoek, 90: 159-169. 